\title{
JĘZYKOZNAWSTWO KOGNITYWNE I KORPUSOWE W BADANIACH NAD PRZEKŁADEM JĘZYKA PRAWNEGO NA PRZYKŁADZIE KODEKSU SPÓLEK HANDLOWYCH I KODEKSU PRACY
}

\footnotetext{
Zarys treści: Artykuł przedstawia analizę tłumaczenia języka prawnego na przykładzie trzech jednostek semantycznych: stosunek pracy - employment relation/relationship, skreślone - delete vs. repealed vs. abrogated, i przepisy karne criminal/penal provisions. Opis ich znaczenia konceptualnego składa się z następujących komponentów: (1) prezentacja definicji słownikowych badanych fraz/wyrazów, (2) analiza danych korpusowych, (3) cytaty z oryginalnych polskich i angielskich aktów prawnych oraz ich przekład, (4) analiza kognitywna. Po dokonaniu powyższej analizy zasugerowane zostały optymalne rozwiązania dla tłumacza.
}

N iniejszy artykuł ma na celu zbadać semazjologiczne aspekty wybranych jednostek semantycznych obecnych w polskich kodeksach prawa i ich angielskich odpowiednikach na tle anglojęzycznych aktów prawnych (Employment Act 2002 i Companies Act 1985). Badany język prawa to język specjalistyczny. Cech dystynktywnych, które pozwalają odróżnić język ogólny od specjalistycznego (technolektu), jest wiele, z czego najważniejsze to: dążenie do precyzji (monosemii), uproszczona składnia, definiowanie pojęć, używanie skrótów, unikanie synonimii, indyferentyzm emocjonalny, rozbudowana leksyka (terminologia), zapożyczenia leksykalne z języków obcych, częsta nominalizacja i derywacja, wysoki stopień terminologizacji (nasycenia terminami), częste występowanie wskaźników spójności tekstu, tzw. konektorów (anafory i katafory), oraz środków utrzymania normy stylistycznej, tzw. hipoterminów (Pieńkos 2003: 101-13; Lukszyn i Zmarzer 2001: 29-53). 
Pieńkos twierdzi, że spośród wszystkich języków specjalistycznych język prawa charakteryzuje się największą polisemią, co wynika z różnorodności systemów prawnych na świecie (Pieńkos 2003: 289). Rola tłumacza tekstów prawnych jest więc specyficzna, zakłada bowiem zmaganie się z wieloznacznością w dążeniu do precyzji wypowiedzi, która w tłumaczeniu tekstów prawnych i prawniczych ma szczególne znaczenie ze względu na ponoszoną przez tłumacza (przysięgłego) odpowiedzialność prawną za jego właściwą interpretację. Równocześnie jednak wymaga się od tłumacza trudu, jak to nazywa Pieńkos, „wydobywania odrębnych rzeczywistości” narzuconych przez różne systemy prawne. Podobnie tłumaczenie postrzega Hejwowski, choć nie ogranicza się w tych spostrzeżeniach jedynie do tekstów prawnych, pisząc, że „każdy tekst jest niczym okno pozwalające nam zobaczyć ogromną, skomplikowaną rzeczywistość i dopiero znajomość tej rzeczywistości (bez której możemy patrzeć, ale nie widzieć) pozwala tłumaczowi dokonać pełnego przekładu tekstu" (Hejwowski 2004: 29). Oprócz lingwistów konieczność eksploracji dwóch rzeczywistości podkreślają też sami prawnicy:

Tłumacz musi wiedzieć, jak zachować ekwiwalencję między pojęciami i terminami należącymi do dwóch odmiennych systemów prawnych i językowych. Zasadą podstawową jest zachowanie stałego związku z kulturą języka źródłowego. (Jabłońska-Bonca 2004: 252)

Lukszyn i Zmarzer (2001: 52) zauważają ponadto, że teksty z zakresu prawa (podobnie jak dotyczące polityki, sztuki i sportu) charakteryzują się bardzo wysoką frekwencją użycia hipoterminów, które funkcjonują jako podstawowy, językowy znak konwencjonalny. Przykładem hipoterminu może być użycie specyficznych czasowników, rzeczowników i przymiotników, które w dyskursie prawnym mogą wywoływać nieco inne skojarzenia niż w języku potocznym (ograniczone do kontekstów prawnych). I tak: w tekście prawnym typowym czasownikiem procesywnym może być podlegać (karze), przekształcać czy likwidować (spółkę); grupami nominalnymi - komisja (rewizyjna), likwidatorzy (spółki), umowa (o pracę), stosunek (pracy); umowa (spółki), akcje i udziały (spółki), zarzad, akcjonariusz; a przymiotnikami - dominujaca (spółka), nieokreślony (czas), odpowiednio (np. przepisy, które stosuje się ). Jak wynika z powyższych przykładów, hipoterminy mają ograniczoną paradygmatykę. $\mathrm{W}$ technolekcie prawnym typowe są również inne cechy hipoterminów: brak trybu rozkazującego, brak odpowiedników rzeczowników w rodzaju żeńskim (np. powierniczka, wspólniczka, partnerka), brak deminutywów (np. działeczka, komisyjka, zgromadzonko), występowanie szeregów 
synonimicznych, np. binomials (null and void). Pozostałe znaki konwencjonalne typowe dla technolektu prawnego, rozróżnione przez Lukszyna i Zmarzer, to znaki pomocnicze, w pierwszej kolejności terminy i/lub nomeny, oraz drugoplanowy znak konwencjonalny - quasi-terminy. Do nomenu i quasiterminu powrócimy jeszcze w dalszej części artykułu. Podsumowując charakterystykę języka prawnego, Lukszyn i Zmarzer przedstawili to za pomocą następującej formuły (2001: 52):

$$
\text { hT }[\mathrm{N} / \mathrm{T}, \mathrm{qT}] \text {, }
$$

gdzie hT to hipotermin, który jako pierwszoplanowy znak konwencjonalny umieszczony jest przed nawiasem, $\mathrm{N}$ i $\mathrm{T}$ to nomeny i terminy - drugoplanowe znaki konwencjonalne, oraz qT oznaczające quasi-terminy, występujące po przecinku jako ostatnie $\mathrm{w}$ sekwencji, $\mathrm{z}$ uwagi na stosunkowo najmniejszą frekwencję w tekstach prawnych spośród rozróżnionych znaków konwencjonalnych.

Jak już wspomniałam, w części badawczej artykułu analizie poddano kilka wybranych jednostek semantycznych typowych dla języka prawnego. Celowo unikam stwierdzenia, że analizie poddane będą określone terminy specjalistyczne, gdyż mając na uwadze taksonomię terminologiczną Lusznyna i Zmarzer, przedmiotem niniejszego artykułu są raczej quasi-terminy niż terminy (Lukszyn Zmarzer 2001). Termin bowiem to:

wyraz (połączenie wyrazowe) o konwencjonalnie określonej, ściśle zdefiniowanej strukturze pojęciowej, w zasadzie jednoznaczny i nie podlegający interpretacji o charakterze emocjonalnym, posiadający natomiast zdolności systemotwórcze. (Lukszyn, Zmarzer 2001: 21)

Podczas gdy termin jest pojęciem teoretycznym, tj. znakiem kodującym „jednostkę konceptualną [...] w systemie relacji semantycznych [...] właściwych dla danej teorii”, pojęcie empiryczne, które jest „konstruktem doświadczanego obiektu [...] jako elementu określonego ugrupowania [...], którego spójność ma charakter przede wszystkim pragmatyczny", zaklasyfikowano jako nomen (Lukszyn, Zmarzer 2001: 32, 40). Nomen jest więc formą poszukiwania terminu, „narzędziem porządkowania doświadczanych obiektów” w klasy obiektów o określonych cechach wspólnych.

Podobnie jak nomen, inną formą poszukiwania właściwego terminu jest quasi-termin. Jego cechą dystynktywną jest fakt, iż jest on „semantyczną zmienną", w przeciwieństwie do terminu, który jest jednostką stałą i ugrun- 
towaną („semantyczny konstant”), co oznacza, że „definicja odpowiednich pojęć jest permanentnie poszukiwana", a w wyniku tych poszukiwań z wyrazu ogólnego wyprowadza się definicję fachową. Quasi-termin jest formą wyodrębniania się właściwego pojęcia (terminu teoretycznego) następującego w procesie jego derywacji (transpozycji semantycznej) z wyrazów ogólnych. Tak więc na osi wyraz ogólny-quasi-termin (lub nomen)-termin zajmuje on pozycję pośrednią. Niniejszy artykuł prezentuje właśnie pewną formę poszukiwań odpowiednich ekwiwalentów kilku wybranych jednostek semantycznych, które zakotwiczone są w językoznawstwie kognitywnym i wzbogacone danymi uzyskanymi z korpusów językowych.

W tym miejscu warto jeszcze wspomnieć o dotychczasowych badaniach poświęconych językowi i terminom prawnym, w szczególności występującym w przekładach kodeksu spółek handlowych. Analizy kodeksu spółek handlowych i ich trzech wersji w języku angielskim (wydanych przez C.H. Beck, TEPIS i Zakamycze) podjęła się w ujęciu pragmatycznym, komunikacyjnym i lingwistyki tekstu Jopek-Bosiacka (2006, rozdz. 4). Autorka słusznie zauważa, że kłopotliwe dla tłumacza mogą być niektóre kwestie terminologiczne związane z władzami spółek, np. terminy zarząd i rada nadzorcza. Bardziej szczegółową analizę znaczenia i tłumaczenia zarządu spółki przedstawia Kierzkowska (2002: 109-111). Warto zwrócić uwagę na fakt, że problemy dotyczące ekwiwalencji terminologicznej mogą też powstać z powodów pozajęzykowych, np. różnic w systemie prawa w różnych państwach, o czym również wspomina Jopek-Bosiacka. Jak opisuje szczegółowo A. Kidyba (2006: 528-531), brytyjski system to przykład monistycznego, a polski i większości krajów UE - dualistycznygo modelu spółki. Ten pierwszy dotyczy spółek, w których jeden organ (board of directors) spełnia funkcje dzielone w modelu dualistycznym przez dwa organy, mianowicie radę nadzorcza (supervisory board) i zarzad (management board ${ }^{1}$ ). System monistyczny jest „zupełnym novum dla polskiego systemu prawa spółek", jednocześnie jednak od roku 2005 (ustawa z 04.03.2005 oraz art. 38 rozp. 2157/2001 dot. spółek europejskich) zezwala na dokonanie przez spółkę wyboru między systemem mono- i dualistycznym.

Innym ciekawym przykładem, opisanym przez Żebrowskiego (2003) oraz Jopek-Bosiacką (2006) jest umowa spółki, która teoretycznie może być przetłumaczona na wiele sposobów, np. memorandum of association (lub incorporation w spółkach amerykańskich) czy articles of association (lub incorporation). Kwestia umowy spółki również rozważana jest przez Kierzkowską

1 Ten często używany przez prawników termin tłumaczony jest również jako corporate governance (por. np. Domański 2005). 
(2002: 111-113). Problem z przetłumaczeniem tego terminu wynika, podobnie jak $\mathrm{w}$ poprzednim przykładzie, $\mathrm{z}$ różnicy $\mathrm{w}$ przepisach dotyczących powstania spółki w dwóch różnych systemach prawa. W Polsce bowiem wystarczy skonstruowanie jednej umowy ( ${ }^{2}$ przypadku większości spółek - statutu sporządzonego $\mathrm{w}$ formie aktu notarialnego), natomiast $\mathrm{w}$ common law wymagane są dwa dokumenty, $\mathrm{z}$ których jeden (memorandum of association) określa działania spółki na zewnątrz ${ }^{3}$, a drugi (articles of association) reguluje jej strukturę wewnętrzną ${ }^{4}$. Sam akt rejestracji spółki w prawie brytyjskim natomiast udokumentowany jest świadectwem rejestracji (certificate of incorporation). Do tego zresztą terminu nawiązuje tłumaczenie wydawnictwa $\mathrm{Za}$ kamyczne, proponujące termin deed of incorporation (zamiast memorandum of association, oznaczający akt założycielski", czyli akt dotyczący zewnętrznego funkcjonowania spółki). W ten sposób tłumaczenie aktu założycielskiego jako deed of incorporation zawiera dwie ważne informacje dla obcokrajowca: po pierwsze, że spółkę w Polsce zakładamy poprzez zawarcie aktu notarialnego, i po drugie, że wpis do rejestru (w Krajowym Rejestrze Sądowym, po uprzednim zatwierdzeniu przez sąd rejonowy) jest równoznaczny z uzyskaniem przez spółkę osobowości prawnej. Według prawa angielskiego taką osobowość prawną (incorporation) spółka otrzymuje po uzyskaniu świadectwa rejestracji, bez wcześniejszego sporządzenia statutu spółki w formie aktu notarialnego. Tłumacząc akt założycielski jako articles of association, memorandum of association lub founding act (wg. tłumaczenia wydawnictwa C.H. Beck), nie oddalibyśmy różnicy między anglosaskim i polskim systemem prawnym, ani też nie zawarlibyśmy informacji o rejestracji spółki (czyli nadaniu jej osobowości prawnej) ${ }^{5}$.

Te i inne problemy terminologiczne wynikające $\mathrm{z}$ różnic $\mathrm{w}$ prawie $\mathrm{i}$ tradycji między państwami opisują również D. Kierzkowska (2002), w książce w całości poświęconej językowi prawa, i I. Malinowska (2004), która w tomie pod swoją redakcją zajmuje się przede wszystkim aspektami zarówno języko-

${ }^{2}$ Wspólnicy zobowiązują się w umowie spółki „dążyć do osiągnięcia wspólnego celu przez wniesienie wkładów oraz jeżeli umowa albo statut tak stanowi, przez współdziałanie w inny sposób", przy czym wysokość wkładów to essentialia negotii (Kidyba 2006: 220).

$3,[\ldots]$ an outward-looking document informing the general public of the company name, its share capital, the address of its registered office, the objects of the company [...] and a statement that the liability of its members is limited" (Dignam, Lowry 2006: 6).

${ }^{4},[\ldots]$ an inward-looking set of rules governing the running of the company. They form the core of the organizational structure of the company" (Dignam, Lowry 2006: 7).

${ }^{5}$ Więcej na temat aspektów prawnych i tłumaczeniowych terminu umowa spółki: Bączkowska 2000. 
znawczymi, jak i kulturowo-cywilizacyjnymi (2004: 8). Terminy przytoczone powyżej, nazwijmy je prawno-kulturowe, choć ciekawe i z pewnością zasługujące na dalszą analizę, zostały już w pewnym stopniu zbadane i dlatego nie stanowią przedmiotu niniejszego artykułu, który zamiast na terminach prawno-kulturowych koncentruje się na kwestii rzadziej poruszanej przez badaczy, mianowicie na quasi-terminach języka prawnego, a w szczególności na poszukiwaniu ich własności konceptualno-semantycznych.

Zanim przejdziemy do quasi-terminów, warto jeszcze przypomnieć fakt natury bardziej ogólnej, a mianowicie, że analiza tekstów prawnych może być dwojaka. Dokonana przez prawników nawiązuje zwykle do logiki oraz filozofii prawa i jest przedmiotem rozważań nauk filozoficznych oraz pozytywnych o prawie (Morawski 2005: 11-12). Warto odnotować, że L. Morawski (2005) nadmienia o lingwistycznej analizie języka prawa przy okazji definiowania nauk przypisanych nieszczegółowym naukom o prawie, podczas gdy J. Jabłońska-Bonca (2004: 30, 178) oraz A. Korybski i in. (2005: 23) o językowej analizie prawa wspominają w kontekście nauk szczegółowych, tj. dogmatyczno-prawnych. J. Jabłońska-Bonca (2004: 30) formułuje to następująco: „logiczno-językowa refleksja nad prawem prowadzona jest w ramach nauk dogmatycznoprawnych, tj. szczegółowych nauk prawnych zajmujących się interpretowaniem, komentowaniem i ocenianiem norm poszczególnych gałęzi prawa”. Wydaje się, że przedmiot zainteresowania filozofii prawa i jednocześnie nauk dogmatycznoprawnych mogą stanowić przepisy de lege lata (obowiązujące), podczas gdy przedmiotem badań głównie nauk dogmatycznoprawnych pozostają przepisy de lege ferenda (tworzone).

Bez względu na to, czy analizę języka prawa przypiszemy naukom dogmatycznoprawnym, czy filozoficznym, celem tego opisu jest dążenie do lex clara, a więc do unikania wypowiedzi nieostrych. Osiągnąć to można poprzez precyzyjne ${ }^{6}$ zdefiniowanie pojęć, słów i zwrotów użytych w normach prawnych (charakter normatywny), a w szczególności w przepisach prawnych. Dotyczy to z pewnością języka użytego w przepisach de lege lata, chociaż ten niezwykle ważny etap precyzowania pojęć wydaje się bardziej dotyczyć języka proponowanego, który dopiero ma być użyty w tworzonych przepisach de lege ferenda. Tak jedna, jak i druga analiza natomiast przyczyniają się do wy-

${ }^{6}$ Nie zawsze jednak język prawa może być precyzyjny. Morawski (2005: 127) wyjaśnia, że „to czy i w jakim zakresie należy posługiwać się językiem precyzyjnym zależy w dużym stopniu od celów, które stawia sobie normodawca”. Problem wyboru języka aktu lub przepisu zależy w dużym stopniu od tego, czy normodawca chce maksymalnie skrępować organy stosujące prawo, czy też raczej chce im pozostawić pewien margines swobody". 
pracowania pewnych norm i szczegółowych zaleceń (charakter normatywny i preskryptywny), co do znaczenia i uzusu ${ }^{7}$ języka prawnego. Jest to zadanie istotne i trudne, bowiem - jak przyznają sami prawnicy - „wyrażenia języka prawnego są bardzo często nieostre, niejasne, wieloznaczne lub po prostu semantycznie niedookreślone (otwarte), i to jest pierwszy - i jak się wydaje najczęstszy - powód, dla którego prawnik musi dokonywać interpretacji” (Morawski 2005: 160).

Rację prawnikom przyznają również poloniści językoznawcy, którzy zauważają, jak często język prawa bywa nieprecyzyjny i jakie z tego tytułu rodzą się zbędne koszty, zarówno finansowe ponoszone przez podatników, jak i psychiczne uderzające w osoby, których dane prawo obowiązuje. Na przykładzie ustawy o tytułach i stopniach naukowych problem ten szczegółowo omawia H. Jadacka w niezwykle interesującym artykule Wymierne i niewymierne koszty niejasności tekstów prawnych (2004).

Charakter deskryptywny (raczej niż preskryptywny) ma najczęściej analiza tekstów prawnych, których podejmują się językoznawcy. Zwykle obejmuje ona kwestie semantyki, składni, poznania, terminologii czy stylistyki. Jest to zresztą zadanie stosunkowo młodej dziedziny językoznawstwa, jaką jest juryslingwistyka (Pieńkos 2003, rozdz. 7.2). Ponieważ jest ona na przecięciu prawa i językoznawstwa stosowanego, w kręgu zainteresowań juryslingwistyki pozostają dwa teksty - źródłowy i docelowy, oraz dwa podstawowe zagadnienia umożliwiające prawidłową interpretację - język i dwa systemy prawne.

W przeciwieństwie do juryslingwisty, prawnik interesuje się tylko jednym tekstem (źródłowym lub docelowym), bowiem jego celem jest interpretacja tekstu (wykładnia prawa) w obrębie jednego systemu prawnego. Drugim potencjalnym zainteresowaniem prawnika może też być sam język prawa użyty w tekstach prawnych. Analizowany jest on jednak według odmiennych metodologii niż te stosowane przez lingwistów (por. Malinowski 2006).

Bez względu na zastosowane metodologie wydaje się, że zarówno logika i filozofia języka badająca wykładnię prawa, dążąca do precyzji i ujednoznaczenia terminologii fachowej (perspektywa normatywna i preskryptywna), jak i językoznawstwo opisujące uzus językowy w konkretnym kontekście (perspektywa deskryptywna), choć odwołują się do odmiennych teorii i metodologii, stanowią istotny wkład do lepszego rozumienia (wykładnia) jak i konstruowania oraz tłumaczenia języka prawa (językoznawstwo), tak więc te dwa podejścia, choć różne, są komplementarne.

\footnotetext{
7 Przykładem uzusu języka prawnego mogą być również teksty prawno-prawnicze, np. dokumenty sądowe i administracyjne (pozwy, wnioski, ekspertyzy itp., por. Kierzkowska 2002: 18-19).
} 
Jak zauważa A. Jopek-Bosiacka (2006: 17), badań językoznawczych nad językiem prawa jest jednak niewiele, a te które istnieją dotyczą zwykle składni tekstów administracyjno-prawnych. Mówiąc o badaniach anglistów nad językiem prawa, warto zauważyć prace B. Kielar (1977), J. Tomaszczyka (1999) czy K. Koseckiego (w druku). Jopek-Bosiacka zauważa też rażący brak badań nad językiem prawa z zakresu pragmatyki oraz językoznawstwa kognitywnego. $\mathrm{W}$ istocie - badań $\mathrm{z}$ zakresu translacji w ujęciu językoznawstwa kognitywnego (Langacker 1987, Talmy 2000) nad przekładem języka prawa jest niewiele. Wspomnieć jednak należy o badaniach nad wykorzystaniem językoznawstwa kognitywnego w przekładzie języka ogólnego, które zaproponowała E. Tabakowska (1993). O zastosowaniu językoznawstwa kognitywnego $\mathrm{w}$ analizie języka prawnego dowiedzieć się można $\mathrm{z}$ licznych prac Krzysztofa Koseckiego (np. 2003, 2004, 2005), który analizuje metaforę i metonimię w tekstach prawnych, opierając się między innymi na teorii metafory zaproponowanej przez G. Lakoffa i M. Johnsona (1980). Choć nie bezpośrednio związane z językoznawstwem kognitywnym, niezwykle interesujące są również badania statystyczne - korpusowe - języka prawnego, które w odniesieniu do języka polskiego prawnego prowadzi Malinowski (2006), a Goźdź-Roszkowski w ramach projektu PELCRA bada angielski język prawny. Intencją autorki niniejszego artykułu natomiast jest przedstawienie analizy języka prawa w ujęciu zarówno semantyki kognitywnej, jak i językoznawstwa korpusowego oraz zastosowanie wyników tej analizy w przekładzie.

\section{Analiza}

Poniższa analiza dotyczy kilku fraz, mianowicie: (1) stosunek pracy-employment relation/relationship, (2) skreślone - delete vs. repealed vs. abrogated, i (3) przepisy karne - criminal/penal provisions. Opis ich znaczenia konceptualnego składa się z następujących komponentów: (1) prezentacja definicji słownikowych badanych fraz/wyrazów, (2) analiza danych korpusowych, (3) cytaty $\mathrm{z}$ oryginalnych polskich i angielskich aktów prawnych oraz ich przekład, (4) analiza kognitywna. Po dokonaniu powyższej analizy zasugerowane są optymalne rozwiązania dla tłumacza. 


\title{
Stosunek pracy: employment relation vs. relationship
}

\author{
Polish Labour Code (wyd. C.H. Beck):
}

art. 22. [Stosunek pracy]. \$1. Przez nawiązanie stosunku pracy pracownik zobowiązuje się do wykonywania pracy określonego rodzaju na rzecz pracodawcy i pod jego kierownictwem oraz w miejscu i czasie wyznaczonym przez pracodawcę, a pracodawca - do zatrudnienia pracownika za wynagrodzeniem;

art. 22. [Employment relation]. $\$ 1$. By establishing an employment relation an employee undertakes to carry out a certain kind of work for the benefit of and under the guidance of an employer, in a location and at times designated by the employer, and the employer undertakes to employ the employee in return for remuneration.

Badania kwalitatywne oparte na definicjach słownikowych potwierdzają intuicyjną opinię autorki i dowodzą, że relation używany jest w kontekstach sugerujących płytki lub tymczasowy związek między dwoma obiektami opisu (bytami). Słownik PWN/Oxford podaje ciekawy przykład następującego wyrażenia oraz jego tłumaczenie:

to have business relations with $s b$ - 'utrzymywać $\mathrm{z}$ kimś stosunki na stopie zawodowej,

co implicytnie sugeruje, że byt A (trajektor) utrzymuje stosunki jedynie na stopie zawodowej, tj. nie utrzymuje stosunków bardziej zażyłych (na stopie prywatnej). Z powyższego może wynikać, że relation implikuje relacje powierzchowne. Dla porównania, pod hasłem relationship mamy przykłady sugerujące bliższy i silniejszy związek emocjonalny między dwoma bytami i/lub ich większą otwartość czy też większą gotowość ujawnienia informacji na swój temat (A - trajektor i B - landmark): a father-son relationship, an actor's relationship with the audience, doctor-patient relationship, sexual relationship. Trzeba zauważyć, że pojawia się pod tym hasłem również a working relationship i jego tłumaczenie 'stosunki na stopie zawodowej', co pozwala stwierdzić, że stosunki zawodowe można przetłumaczyć dwojako, prawdopodobnie jednak z domyślnym różnym stopniem znajomości.

Badania kwantytatywne oparte na tych danych korpusowych pozwalają zauważyć, że employment relation jest używane znacznie rzadziej niż employment relationship: zaledwie 5\% wszystkich przykładów dotyczy relation i aż 
95\% dotyczy relationship. W korpusie ogólnym znajdujemy również i inne przykłady kolokacji, które potwierdzają wcześniejsze obserwacje. I tak, relation używany jest do określenia konfiguracji abstrakcyjnych i potencjalnych oraz sugerujących odległość między TR i LM (abstract, ambivalent, apparent, distant RELATION). Ponadto relation używany jest również w celu porównawczym i/lub przeciwstawnym, aby wykazać pewną analogię między dwoma obiektami opisu w relacji lub ich relację w stosunku do trzeciego obiektu, $\mathrm{z}$ którym są one porównywane (analogous, binary RELATION). Relationship natomiast występuje w kontekstach kodujących długoterminowy związek ( lasts, $\sim$ is continuoued/developed, consistent, continuing), wynikający ze zobowiązań prawnych (business, contractual, constitutional), profilujący ścisły związek opisywanych obiektów (blood, amicable, mother/child), oraz podkreśla obopólną zależność dwóch podmiotów (addresser/addressee, employer) employee, mother/child, banker/customer relationship).

W korpusie utworzonym na potrzeby niniejszego badania, który składa się w całości z treści brytyjskiego Employment Act 2002 i liczy około 30 tysięcy tokenów, można zauważyć, że relation występuje jedynie we frazie in relation to, natomiast relationship występuje $\mathrm{z}$ osobą (person, child, newborn, mother itd.).

Uwzględniając powyższe przykłady, w ujęciu językoznawstwa kognitywnego można przyjąć hipotezę, że relation sugeruje statyczny obraz, w którym dwa byty są sobie przeciwstawione, są ze sobą porównane lub wskazuje się na ich wzajemne, abstrakcyjne powiązania. Status i struktura wewnętrzna tych bytów nie ulegają jednak zmianie, bowiem profilowane jest jedynie ich (abstrakcyjne) powiązanie znaczeniowe. Taki układ TR-LM nie jest więc uzasadniony ontologicznie, a raczej epistemologicznie, bowiem wynika on np. z postrzegania relacji TR-LM w takich a nie innych kategoriach przez konkretnego konceptualizatora (interlokutora) i dotyczy zwykle konkretnej sytuacji ('tui-teraz'), kiedy taka relacja jest konstruowana. W takim związku TR-LM profilowana jest sama relacja oraz informacje, które z niej wynikają, a nie byty (TR, LM) jako takie (por. rysunek 1a).

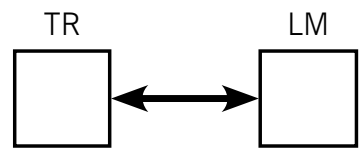

Rys. 1a Relation 
Analizując wcześniej przytoczone przykłady kolokacji z relationship, można przyjąć, że relationship dotyczy dwóch bytów związanych ze sobą w sposób bardziej stały, trwający już przed lub od momentu, kiedy się o nim mówi (a nie jedynie 'tu-i-teraz'). Związek dwóch bytów jest również silniejszy, bardziej wiążący i uzależniający, prawdopodobnie więc ingerujący w ich wewnętrzną strukturę, tj. zmieniający w jakimś stopniu cechy każdego bytu i/lub tworzący swoisty nowy byt (ontologiczny charakter zmian). Na przykład związek pracodawcy i pracownika potwierdzony umową o pracę znacząco wiąże obydwie strony, ograniczając ich autonomiczność (czynności prawne), tworząc oddzielny homogeniczny byt (związek, układ, firmę, spółkę, korporację itp.). W tej relacji wydaje się, że profilowany jest byt nadrzędny, utworzony z dwóch (lub więcej) bytów składowych, z czego jeden (pracodawca) pełni istotniejszą, dominującą rolę w stosunku do drugiego, podległego bytu (pracownik). Mamy tu więc do czynienia z trzema bytami: podrzędnym (pracownik), dominującym (pracodawca) oraz nadrzędnym (firma, korporacja). W badanym wyrażeniu byt dominujący jest, jak się wydaje, identyfikowany $\mathrm{z}$ bytem nadrzędnym (por. rysunek $1 \mathrm{~b}$ ). Układ ten ilustruje konceptualizację, która zakłada względne utożsamianie TR i LM, tj. w tym wypadku pracownika z danym pracodawcą/instytucją.

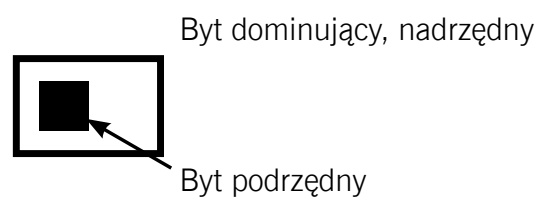

Rys. 1b Relationship

W tym miejscu można by się pokusić o rozpatrzenie innego jeszcze rodzaju związku TR i LM, który jest wariantem powyższego przypadku, mieści się on bowiem w zakresie pojęcia relationship, choć realizuje raczej jego nieprototypowe znaczenie. Na przykład gdyby obydwa byty zachowały względną niezależność i jedynie w ograniczonych kontekstach (umowach, czasie realizacji konkretnego projektu/zamówienia) łączyły je silniejsze związki (handlowe, prawne) wpływające na ich wewnętrzną strukturę (charakter, oferta firm), wówczas profilowany byłby raczej byt nadrzędny. $Z$ uwagi na swoją tymczasowość (określoną konkretnymi umowami) na poniższym rysunku profil zaznaczony jest linią przerywaną (por. rysunek 1c). Taki układ mógłby sugerować, że byt podrzędny (pracownik) nie byłby utożsamiany $\mathrm{z}$ jednym bytem nadrzędnym (pracodawcą); pracownik mógłby np. wykonywać usługi dla kilku 
pracodawców/instytucji. Pomimo że związki łączące takie byty nie są chyba tak silne jak te zilustrowane rysunkiem $1 \mathrm{~b}$, pojęcie relationship nadal wydaje się bardziej adekwatne dla określenia relacji TR-LM niż relation, bowiem nawet $w$ takim mniej (proto)typowym (peryferyjnym?) związku TR i LM wchodziłyby w interakcję, podczas gdy związek TR i LM określony pojęciem relation wydaje się pozbawiony takiej wewnętrznej ingerencji, pozostając tym samym jedynie bytem przywoływanym na poziomie abstrakcyjnym.

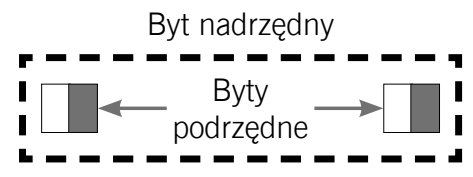

Rys. 1c Relationship

Na koniec przyjrzyjmy się jeszcze użyciu badanych słów w tekstach anglojęzycznych. Dla przykładu w Employment Law autorstwa Deborah Lockton, podręczniku dla studentów prawa $\mathrm{w} \mathrm{W}$. Brytanii, rozdział drugi zatytułowany jest The Employment Relationship, podrozdział pierwszy z kolei dotyczy natury stosunku pracy, tj. the nature of the relationship. W pierwszym zdaniu rozdziału drugiego czytamy:

It may seem a fairly obvious statement, but the two parties who make up an employment relationship are an employee and an employer.

Literatura anglojęzyczna dowodzi, że preferowanym ekwiwalentem polskiej frazy stosunek pracy jest employment relationship, co również potwierdza słuszność przeprowadzonej powyżej analizy kognitywno-korpusowej. W kontekście powyższych rozważań wydaje się, że dla potrzeb dyskursu prawnego trafniejszym wyborem jest employment relationship niż employment relation.

\section{Skreślono: deleted vs. repealed vs. abrogated}

Słownik PWN-Oxford definiuje repeal jako uchylić i określa to słowo jako typowe dla języka prawnego. Dane korpusowe pozwalają zauważyć, że repeal zwykle łączy się z Act lub legislation. Podobnie przetłumaczone jest abrogate jako uchylić prawo, jednak bez informacji o ograniczeniu się do kontekstów prawnych, który towarzyszył repeal. Łączy się on z takimi słowami, jak law, 
constitution, i treaties i występuje w kontekstach formalnych (formally, unilaterally). Z kolei delete ma odmienne znaczenie: używane jest dla określenia mechanicznej czynności wykreślenia czegoś za pomocą gumki do mazania lub skasowania czegoś za pomocą komputera. Również teksty medyczne zawierają delete i występują z np. DNA czy tumour w sensie usunąć. A zatem delete użyte w tekście prawnym dla wyrażenia skreślenia paragrafu/artykułu wydaje się najmniej trafnym wyborem, co potwierdzają również dane korpusowe.

Przyjrzyjmy się teraz definicjom w słowniku monolingwalnym (Collins Electronic Dictionary):

repeal $v b .(t r$.

1. to annul or rescind officially (something previously ordered); revoke: these laws were repealed.

2. Obsolete. to call back (a person) from exile.

3. an instance or the process of repealing; annulment.

[from Old French repeler, from RE- + apeler to call, APPEAL]

\section{abrogate}

(tr.) to cancel or revoke formally or officially; repeal; annul.

[from Latin abrogātus repealed, from AB-1 + rogāre to propose (a law)]

delete

(tr.) to remove (something printed or written); erase; cancel; strike out.

[from Latin dēlère to destroy, obliterate; obliterate

(tr.) to destroy every trace of; wipe out completely.]

Czasownik delete koduje czynności najbardziej radykalne i destrukcyjne pozbycie się śladów czegoś. Takie działanie zakłada, że w mechaniczny sposób pozbywamy się obiektu fizycznego, którego doświadczamy materialnie. Dwa pozostałe przykłady dotyczą bardziej abstrakcyjnego bytu, mianowicie aktu ogłoszenia jakiegoś komunikatu (np. przepisu lub normy). Należy też przyjąć, że procesy wyrażone zarówno przez abrogate, jak i repeal nie mają na celu unicestwienia śladu istnienia jakiegoś bytu, a jedynie odwołanie jego mocy prawnej. Delete profiluje więc stan poprzedni do opisu i czynność do wykonania na opisywanym obiekcie (istnienie czegoś oraz jego zniszczenie), natomiast abrogate i repeal profiluje stan końcowy (skutek utraty mocy prawnej) oraz stan późniejszy (po anulowaniu istnienia bytu, tu: paragrafu). Przedrostek $a b$ - w abrogate ponadto sugeruje, że jakiś komunikat został ogłoszony (rogāre, por. rogative w pragmatyce Leecha, 1983), a następnie anulowany, tj. odwołany. Przedrostek od- ma więc charakter anulatywny. Ponadto zgodnie 
$\mathrm{z}$ analizą kognitywną podstawa czasownika prefiksalnego, $\mathrm{w}$ tym wypadku wołać, wyrażająca ruch trajektora od punktu źródłowego (PZ) do punktu docelowego (PD), w powyższym kontekście zespojenia z przedroskiem od-, nabywa nowego znaczenia, mianowicie sygnalizuje ruch w odwrotnym kierunku - od PD do PZ, czyli cofanie się czynności wcześniej opisanej (Przybylska 2006: 103-104).

Z kolei czasownik repeal można zinterpretować w taki sposób, że repeal dotyczy ponownego przywołania (re-appeler - 'call back') danego komunikatu (przepisu) i powrót do sugerowanego implicytnie poprzedniego stanu. Przedrostek od- przywołuje ruch na zewnątrz, ilustrując w ten sposób adlatywność, Natomiast przedrostek re- nawiązuje do ruchu do wewnątrz, przy czym wnętrze metaforycznego pojemnika gości TR co najmniej po raz wtóry. Jest więc przykładem na iteratywny ablativus. Adlative wyrażony poprzez ab-/od-ilustrujące rozwiązanie jakiejś sytuacji poprzez oddalenie TR od LM; ablative kodowany przez re-widać również w następujących przykładach:

(1) absolution, abnormal, abaxial, aboral;

(2) odroczenie, odmrożenie, odparcie, odprawić, odstręczać, odprężać, odesłać, odżałować, oddać;

A $\longrightarrow$ B

(3) restoration, recopy, reorder, return.

A $\rightarrow$ B $-\cdots$ A

Podsumowując, delete realizuje inne kombinacje paradygmatyczne niż repeal czy abrogate. Z powyższej analizy korpusowej, słownikowej i kognitywnej należy wywnioskować, że można zdecydowanie odrzucić delete w tekstach prawnych. Mając do wyboru abrogate i repeal bardziej trafne wydaje się abrogate niż repeal, jednak $\mathrm{z}$ uwagi na tradycyjnie przyjęty w aktach prawnych w języku angielskim (w szczególności w W. Brytanii) repeal, jest to wybór bardziej zalecany. 


\section{Przepisy karne: criminal provisions vs. penal provisions}

Słownik PWN-Oxford definiuje criminal jako 'przestępczy', a penal jako 'zagrożony karą, karny, karalny’. Pierwszy przymiotnik sugeruje więc zjawisko już istniejące, natomiast drugi wydaje się wyrażać raczej stany potencjalne oraz czynności/stany, które mają się wydarzyć.

Dane korpusowe potwierdzają powyższe obserwacje oraz dodatkowo pozwalają zauważyć, że criminal występuje ze słowami o silniejszym zabarwieniu emocjonalnym (np. underworld, intentions, problems, violence, assault) lub sugerującymi poważniejsze skutki prawne (liability, intentions, nature) bądź też z wyrazami opisującymi te skutki (accusation, charges, record, sanction, prosecution). Często dotyczą one czynności, które już się wydarzyły (records, history, assaults). Z kolei penal wydaje się kolokować ze słowami bardziej ogólnymi, nie zawsze związanymi z literą prawa sensu stricto, jedynie nawiązującymi metaforycznie do prawa (methods, aims), choć i te dotyczące samego prawa pojawiają się w korpusie (crisis, affairs, matters), oraz z czynnościami (przewinieniami), które trwają (aims, development, reform, treatment) lub dopiero mają się wydarzyć, a kara za nie zostanie dopiero określona.

W nazwach aktów prawnych języka docelowego częściej występuje criminal niż penal, np. prawo karne to criminal law (Criminal Law Act, Criminal Justice Act, Crime and Disorder Act, Criminal Procedure Act, Criminal Damage Act itp.). Tłumaczenie tytułu V KSH, który jest jedną z sześciu podstawowych części tego kodeksu, jako Criminal Provisions nawiązuje więc wyraźnie do angielskich nazw przepisów prawnych użytych w tytułach zbiorów aktów prawnych i nazwy gałęzi prawa - prawa karnego (criminal law). Na poziomie makrostruktury przepisów użyta terminologia wygląda więc następująco:

\begin{tabular}{|l|l|l|}
\hline \multicolumn{1}{|c|}{ Język angielski } & \multicolumn{2}{|c|}{ Język polski } \\
\hline $\begin{array}{l}\text { Nazwa zbioru aktów prawnych: } \\
\text { Criminal Law }\end{array}$ & \multicolumn{2}{|c|}{-} \\
\hline & Tłumaczenie: C.H. Beck & Tłumaczenie: Zakamycze \\
\hline $\begin{array}{l}\text { Part I Statutes } \\
\text { np. Criminal Justice Act, } \\
\text { Companies Act }\end{array}$ & $\begin{array}{l}\text { Nazwa kodeksu: } \\
\text { KSH - Commercial } \\
\text { Companies Code }\end{array}$ & $\begin{array}{l}\text { Nazwa kodeksu: } \\
\text { KSH - Code of Commer- } \\
\text { cial Companies }\end{array}$ \\
\hline- & $\begin{array}{l}\text { Tytuł: np. Przepisy karne } \\
\text { (criminal provisions) }\end{array}$ & $\begin{array}{l}\text { Tytuł: np. Przepisy karne } \\
\text { (penal provisions) }\end{array}$ \\
\hline
\end{tabular}




\begin{tabular}{|l|l|l|}
\hline $\begin{array}{l}\text { Part: np. part XVI (fraudulent } \\
\text { trading by a company) }\end{array}$ & Dział - Division & Dział - Section \\
\hline Chapter & Rozdział - Chapter & Rozdział - Chapter \\
\hline $\begin{array}{l}\text { Section: np. } 458 \text { Punishment for } \\
\text { fraudulent trading }\end{array}$ & Oddział - Section & Oddział - Part \\
\hline
\end{tabular}

Zarówno nagłówki, jak i sama treść przepisów karnych dotyczących spółek handlowych w języku angielskim są inaczej sformułowane (np. „przepisy karne" zastąpiono słowem punishment) i nie mogą być niestety źródłem terminologii dla tłumacza.

[KSH] Art. 585. [Działanie na szkodę spółki]

$\$ 1$. Kto, biorąc udział w tworzeniu spółki lub będąc członkiem jej zarządu, rady nadzorczej lub komisji rewizyjnej albo likwidatorem, działa na jej szkodę podlega karze pozbawienia wolności do lat 5 i grzywnie.

$\S 2$. Tej samej karze podlega, kto osobę wymienioną w $\$ 1$ nakłania do działania na szkodę spółki lub udziela jej pomocy do popełnienia tego przestępstwa.

\section{[Beck] Criminal provisions}

Art. 585. [Acts to the detriment of a company] $₫ 1$. A person who, while participating in the creation of a commercial company or serving as a member of its management board, supervisory board or audit committee or as a liquidator, acts to the detriment of the company, shall be subject to a penalty of imprisonment for up to 5 years and a fine.

$\S 2$. A person who incites a person listed in $₫ 1$ to act to the detriment of the company or aids and abets him in committing this crime shall be subject to the same penalty.

\section{[Zakamycze] Penal provisions}

Art. 585. Any person who, while taking part in the establishment of a commercial company or acting in the capacity of a member of its management board, supervisory board, auditors' committee, or a liquidator, acts to its detriment - shall be liable to penalty of imprisonment of up to five years and a fine. 
[Companies Act] 485 Punishment for fraudulent trading

If any business of a company is carried on with intent to defraud creditors of the company or creditors of any other person, or for any fraudulent purpose, every person who was knowingly a party to the carrying on of the business in that manner is liable to imprisonment or a fine, or both.

This applies whether or not the company has been, or is in the course of being, wound up.

Ciekawe jest to, że na około 30 tysięcy tokenów w korpusie utworzonym na potrzeby niniejszej analizy, składającej się z tekstu Companies Act 1985, słowo criminal pojawiło się jedynie pięć razy, natomiast penal w ogóle nie występuje w tym akcie. Jest natomiast jeden przykład criminal penalties. Konteksty criminal są następujące: civil or criminal (2 razy), criminal penalties, criminal offence, i criminal law. W kontekście provision(s) nie występuje ani criminal, ani penal. W korpusie utworzonym z brytyjskiego Employment Act 2002 (około 31 tysięcy tokenów) pojawia się dwukrotnie criminal proceedings oraz penalties, również istnieje tu odrębna sekcja zatytułowana Employment Act Penalties.

W podsumowaniu powyższych rozważań, biorąc pod uwage kontekst tekstów prawnych, które regulują normy i procedury prawne tego, co in potentia może się wydarzyć, orzec można, że penal provisions wydają się bardziej adekwatnym wyborem tłumacza niż criminal provisions. Natomist criminal jest dobrym wyborem tłumacza w kontekście procedury karnej, która odnosi się do czynów już popełnionych. Powiemy więc penal provisions, ale criminal procedure.

\section{Wnioski}

W artykule przedstawiono kilka przykładów quasi-terminów występujących w języku prawnym. Quasi-termin (qt), jako jednostka semantyczna będąca formą poszukiwań terminów ostatecznych i stałych $(\mathrm{t})$, wyodrębniony jest $\mathrm{z}$ wyrazów ogólnych (wo), i na osi wo-qt-t jest stadium pośrednim, podlegającym ciągłym modyfikacjom i redefinicjom. Przeanalizowane w niniejszym artykule dane to wyrazy ogólne, które użyte w kontekście tekstów prawnych nabierają nieco innego znaczenia, przypisanego dyskursowi prawnemu. O tym, że są to nadal quasi-terminy, a nie usankcjonowane terminy specjalistyczne świadczyć może brak ujednolicenia ich ekwiwalentów w języku docelowym. Niniejszy artykuł miał właśnie na celu ukierunkowanie procesu poszukiwań na zdefiniowa- 
nie i określenie ostatecznych ekwiwalentów analizowanych polskich wyrazów w języku angielskim. Argumentacja, którą się posłużono, wywodzi się z metodologii i teorii semantyki kognitywnej oraz badań korpusowych.

\section{Literatura}

Bączkowska, A. (2008), „»Umowa spółki handlowej« w prawie polskim i brytyjskim: aspekty prawne i przekładoznawcze", [w:] Bączkowska, A., Święcicka, M. (red.), Linguistics Applied, Bydgoszcz.

Dignam, A., Lowry, J., 2006, Company Law, Oxford.

Domański, G. E., 2005, Understanding Modern Company Law, Warszawa.

Hejwowski, K., 2004, Kognitywno-komunikacyjna teoria przekładu, Warszawa.

Jabłońska-Bonca, J., 2004, Wprowadzenie do prawa/Introduction to Law, Warszawa.

Jadacka, H., 2004, „Wymierne i niewymierne koszty niejasności tekstów prawnych", [w:] Język, prawo, społeczeństwo, Malinowska, E. (red.), Opole, s. 151-157.

Jopek-Bosiacka, A., 2006, Przekład prawny i sqqdowy, Warszawa.

Kidyba, A., 2006, Prawo handlowe, Warszawa.

Kielar, B., 1977, Language and the Law in the Aspect of Translation, Warszawa. Kierzkowska, D., 2002, Tłumaczenie prawnicze, Warszawa.

Korybski, A., Leszczyński, L., Pieniążek, A., 2005, Wstęp do prawoznawstwa, Lublin.

Kosecki, K., 2003, „Metafora pojęciowa „»Czas to pieniądz« a struktura umów o pracę w prawie polskim i Europejskim", Rozprawy humanistyczne, Włocławek, s. 73-77.

Kosecki, K., 2004, „Przestępstwo zabójstwa w polskim kodeksie karnym jako kognitywna kategoria radialna", Rozprawy humanistyczne, Włocławek, s. 253-259.

Kosecki, K., 2005, „On Metonymies in the Names of Selected Legal Contracts", Rozprawy Humanistyczne, Włocławek, s. 189-196.

Kosecki, K., (w druku), „Nowe tłumaczenie polskiego kodeksu pracy na język angielski”.

Lakoff, G., Johnson, M., 1980, Metaphors We Live By, 12, Chicago.

Langacker, R., 1987, Foundations of Cognitive Grammar, Stanford.

Leech, G., 1983, Principles of Pragmatics, Harlow. Lockton, D., 2006, Employment Law, Basingstoke. 
Lukszyn, J., Zmarzer, W., 2001, Teoretyczne podstawy terminologii, Warszawa.

Malinowska, E. (red.), 2004, Język - prawo - społeczeństwo, Opole.

Malinowski, A., 2006, Polski język prawny. Wybrane zagadnienia, Warszawa.

Michałowska, K., 2006, Polish Commercial Companies Code, Warszawa.

Michałowska, K., 2004, Polish Labour Law, Warszawa.

Morawski, L., 2005, Wstęp do prawoznawstwa, Toruń.

Pieńkos, J., 2003, Podstawy przekładoznawstwa, Kraków.

Przybylska, R., 2006, Schematy wyobrażeniowe a semantyka polskich prefiksów czasownikowych do-, od-, prze-, roz-, u-, Kraków.

Tabakowska, E., 1993, Językoznawstwo kognitywne a poetyka przekładu, Kraków.

Talmy, L., 2000, Toward a Cognitive Semantics, Cambridge.

Tomaszczyk, J. (red.), 1999, Aspect of Legal Language and Legal Translation, Łódź.

Żebrowski, P. T., 2003, „Angielskie przekłady polskiego kodeksu spółek handlowych 2001. Porównanie, ocena i wnioski dla tłumaczy", Lingua Legis, 11 , s. $57-68$.

[CA] - Companies Act 1985

PCCP - Polish Commercial Companies Code, translated by K. Michałowska, $4^{\text {th }}$ edition, Warszawa: Beck, 2006.

CCP - Code of Commercial Companies, translated by R. Bem, E. Kucharska, J. Marynowicz, A. Mączka, 2 ${ }^{\text {nd }}$ edition, Kraków: Zakamycze, 2004.

\section{Cognitive linguistics and corpus linguistics in research on the translation of legal language: the case of Polish Commercial Companies Code and Labour Code (summary)}

The present paper is concerned with the problem of translating legal language. Three units, excerpted from the Polish Commercial Companies Code and Labour Code, are analysed: (1) employment relationship/relation (pol. stosunek pracy), (2), delete/repealed/abrogated (pol. skreślone), (3) criminal/penal provisions (pol. przepisy karne). The methodology employed in the analysis draws on cognitive linguistics (exploring the conceptual meanings of the items examined) and corpus linguistics (quantitative analysis). Additionally, dictionary definitions and extracts from English acts are also 
taken into account while determining English equivalents of Polish words. The analysis presented in this paper demostrates that legal terminology found in the translations of Polish codes into English is inconsistent. Consequently, the units analysed in this paper are not examples of legal terms; rather they should be assigned the status of what J. Lukszyn and W. Zmarzer call 'quasi-terms' (cf. 2001). 